\title{
Anti-tumor effect of fruit rind of Myristica malabarica in an Ehrlich ascites carcinoma model
}

\author{
Chandrakana Bandyopadhyay ${ }^{1}$, Alak Manna ${ }^{1}$, Soumita De ${ }^{1}$, Nafisha Yasmin ${ }^{1}$, Ajay K. Bauri², \\ Subrata Chattopadhyay ${ }^{2}$, Mitali Chatterjee ${ }^{1 *}$
}

\author{
${ }^{1}$ Department of Pharmacology, \\ Institute of Post Graduate \\ Medical Education and \\ Research, Kolkata, West \\ Bengal, India \\ ${ }^{2}$ Bio-Organic Division, Bhaba \\ Atomic Research Centre, \\ Trombay, Mumbai, \\ Maharashtra, India \\ Received: 31 December 2018 \\ Accepted: 14 February 2019 \\ *Correspondence to: \\ Dr. Mitali Chatterjee, \\ Email: ilatim@vsnl.net \\ Copyright: (C) the author(s), \\ publisher and licensee Medip \\ Academy. This is an open- \\ access article distributed under \\ the terms of the Creative \\ Commons Attribution Non- \\ Commercial License, which \\ permits unrestricted non- \\ commercial use, distribution, \\ and reproduction in any \\ medium, provided the original \\ work is properly cited
}

\begin{abstract}
Background: Among the various modalities of anti-cancer treatment, cancer chemotherapy plays a very vital role. The alarming side effects being its main drawback leads to relentless research for newer agents. A new natural agent with promising anti-cancer properties from in-vitro studies leads to this study. Here we have evaluated the anti-tumor activity of a crude extract of fruit rind of Myristica malabarica in an Ehrlich ascites carcinoma model in mice.

Methods: A murine model of cancer was established with i.p. inoculation of Ehrlich Ascites carcinoma (EAC) cells; animals were divided into five groups (including normal control) to observe the inhibitory effect of a crude extract of the fruit rind of Myristica malabarica/rampatri $(0-100 \mathrm{mg} / \mathrm{kg}$ b.w. i.p.) as compared with methotrexate $(0.4 \mathrm{mg} / \mathrm{kg}$ bw., i.p.). Blood and ascitic fluid were collected on the $10^{\text {th }}$ day for analysis.

Results: In the EAC model, there was an increase in tumor volume, tumor weight, and tumor packed cell volume, which was decreased by rampatri (50 and $100 \mathrm{mg} / \mathrm{kg} \mathrm{bw}$ ) along with an increase in the mean survival time (MST). Rampatri caused minimal alterations in hematological parameters, renal functions remained unchanged but an increase in hepatic SGOT was demonstrated.

Conclusions: The crude extract of rampatri (containing Malabaricones) exhibited significant anti-tumor activity with minimal effect on hematological and renal functions.
\end{abstract}

Keywords: Anti-tumor, Ehrlich ascites carcinoma, Malabaricones, Myristica malabarica, Rampatri

\section{INTRODUCTION}

There is an alarming increase in the incidence of cancer and the World Health Organization status reports in 2012 state an estimated 14.1 million new cancer cases and 8.2 million cancer-related deaths, compared with 12.7 million and 7.6 million, respectively in 2008 (https://gco.iarc.fr/today/data-sources-methods). The prevalence estimates for 2012 show that there were 32.6 million people (>15 years) who had had a cancer diagnosed in the previous five years. Though there is a plethora of cytotoxic drugs available for the treatment of cancer, namely antibiotics, anti-metabolites, alkylating agents, inhibitors of formation of the mitotic spindle or inhibitors of topoisomerases, most of them are costly and have serious side effects that include myelosuppression and gastro-intestinal toxicity. It is relevant that $60 \%$ of currently used anticancer agents are derived from natural sources, including plants, marine organisms, and microorganisms. Considering the rich and diverse flora of India, the search for plant derived compounds is expected to yield important leads. 
Malabaricones are diarylnonanoids containing constituents MAL-A, MAL-B, MAL-C and MAL-D sourced from the fruit rind of the plant Myristica malabarica popularly known as rampatri, Bombay mace or false nutmeg. Its pharmacological activities range from hepatoprotective, anti-ulcer, anti-leishmanial to anticancer activity. ${ }^{1-6}$ The $\mathrm{IC}_{50}$ in cancer cell lines was low as it ranged from $12.3 \pm 1.67$ to $24 \pm 0.44 \mu \mathrm{M}^{4}$ and accordingly, this study was undertaken to study it's in vivo efficacy.

\section{METHODS}

\section{Chemicals}

All reagents were procured from Sigma-Aldrich (St Louis, Mo, USA) except the crude methanolic extract of rampatri.

\section{Animals}

Adult male Swiss albino mice weighing 25-30g were acclimatized for one week in the institutional animal house at a temperature of $25-28^{\circ} \mathrm{C}$, relative humidity of $55 \pm 2 \%$ and a 12 hour light/dark cycle. The mice were grouped and housed in polyacrylic cages, with not more than six animals per cage, water and food pellets were provided $\mathrm{ad}$ libitum. The experimental protocols received prior approval from the institutional animal ethics committee in accordance with the ethical guidelines laid down by the committee for the purpose of control and supervision of experiments on animals (CPCSEA), Govt. of India.

\section{Preparation of rampatri}

A methanolic extract from the fruit rind of Myristica malabarica (Myristicaceae), popularly known as rampatri, Bombay mace or false nutmeg was prepared $(1.0 \mathrm{~g} / \mathrm{ml}$ in DMSO) and stored at $-20^{\circ} \mathrm{C}$. $^{5}$ Just prior to administration, the extract was diluted in phosphate buffered saline (PBS, 20mM, pH 7.4).

\section{Development of an EAC model}

Following centrifugation of mouse Ehrlich ascites carcinoma cells, the supernatant was removed and cell concentration was adjusted to $5 \times 10^{6}$ cells $/ \mathrm{mL}$. Under aseptic conditions, Swiss Albino mice (male, $n=36$ ) were injected these EAC cells $\left(1 \times 10^{6}\right.$ cells, i.p., $\left.0.2 \mathrm{ml} / \mathrm{mouse}\right){ }^{7}$

The control group (Group I, n=6) was randomly reserved before inoculation. Post 24hrs EAC transplantation, animals were then randomly divided into four groups $(n=9)$, wherein group II, served as the EAC control group, group III received methotrexate $(0.4 \mathrm{mg} / \mathrm{kg}$ bw., i.p.) while groups IV and V received rampatri (50 and $100 \mathrm{mg} / \mathrm{kg}$ bw., i.p) respectively for nine consecutive days (Figure 1) (MTX). In each group, 6 mice were euthanized after 24hrs of the last dose to evaluate tumor volume, tumor weight, and tumor packed cell volume, hematological and biochemical parameters, while three were kept for evaluating the mean survival time (MST).

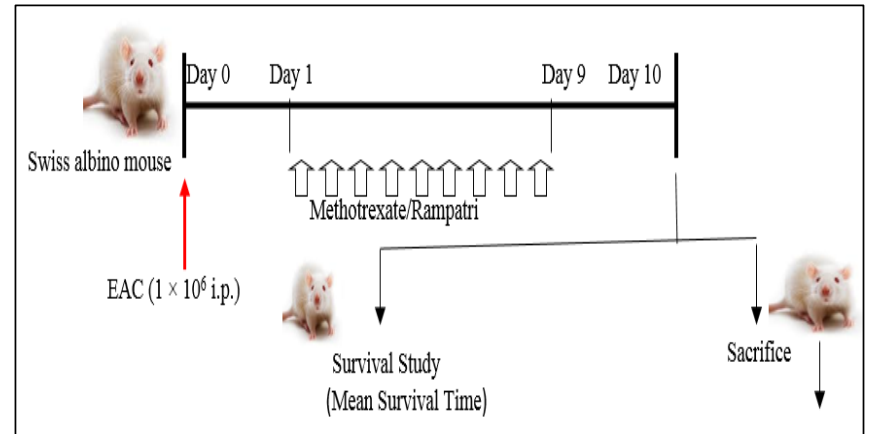

EAC cells $\left(1 \times 10^{6}\right.$ cells, i.p., $0.2 \mathrm{ml} /$ mouse $)$ were inoculated into 36 mice. Post $24 \mathrm{~h}$ EAC transplantation, animals were divided into four groups $(n=9)$, wherein Group II, served as EAC control, Group III received methotrexate $(0.4 \mathrm{mg} / \mathrm{kg}$ bw., i.p.), Groups IV and V received rampatri (50 and $100 \mathrm{mg} / \mathrm{kg}$ bw., i.p. respectively) for nine consecutive days as described in materials and methods.

\section{Figure 1: Study design for evaluation of anti-cancer effect of rampatri.}

\section{Tumor parameters}

The effect of rampatri on tumor growth and host's survival time was assessed in terms of:

\section{Tumor volume}

The mice were dissected and ascitic fluid was collected from the peritoneal cavity. The volume was measured using a graduated centrifuge tube.

\section{Tumor weight}

The tumor weight was measured by taking the weight of the mice before (A) and after (B) collecting the ascitic fluid from the peritoneal cavity.

\section{Tumor packed cell volume}

After collecting the ascitic fluid, the tumor packed cell volume was determined by centrifugation $(1000 \mathrm{~g}$ x 5 minutes).

\section{Determination of mean survival time and percentage increase in life span}

The mortality was monitored by recording percentage increase in life span (\% ILS) and mean survival time (MST) as follows:

$\%$ ILS $=[($ Mean survival time of treated group/ Mean survival time of control group)-1] x 100

\section{Estimation of hematological, renal and liver function tests}

Blood was collected $24 \mathrm{hrs}$ after the last dose, and $18 \mathrm{~h}$ of fasting for estimation of hemoglobin $(\mathrm{Hb}), \mathrm{RBC}$ and WBC 
count, platelet and lymphocyte counts, hematocrit, mean corpuscular volume, in a coulter counter. Urea and creatinine were estimated for evaluation of renal functions, while liver functions were evaluated in terms of serum glutamate oxaloacetate transaminase (SGOT) and glutamate pyruvate transaminase (SGPT), using commercially available kits.

\section{Statistical analysis}

All data were expressed as mean \pm SEM for the laboratory and tumor parameters and survivability. Statistical analysis was evaluated by one-way ANOVA followed by Dunnett's post hoc test using Graph Pad Prism software, version 5(Graph Pad Software Inc., San Diego, CA, USA); $\mathrm{p}<0.05$ were considered as statistically significant.

\section{RESULTS}

\section{Tumor volume}

In the EAC control (Group II), the tumor volume increased to $9.85 \pm 0.84 \mathrm{ml}$ which in the presence of MTX (Group III) led to a significant 2.01 fold decrease to $4.88 \pm 0.27 \mathrm{ml}$ ( $<<0.05$, Figure 2A). Similarly, rampatri (50 and $100 \mathrm{mg} / \mathrm{kg}$ bw., groups IV and V) showed a dose dependent decrease, as the tumor volume decreased by 1.69 and 2.4 fold to $5.80 \pm 0.29$ and $4.00 \pm 0.55 \mathrm{ml}(\mathrm{p}<0.001)$ respectively (Figure 2A).
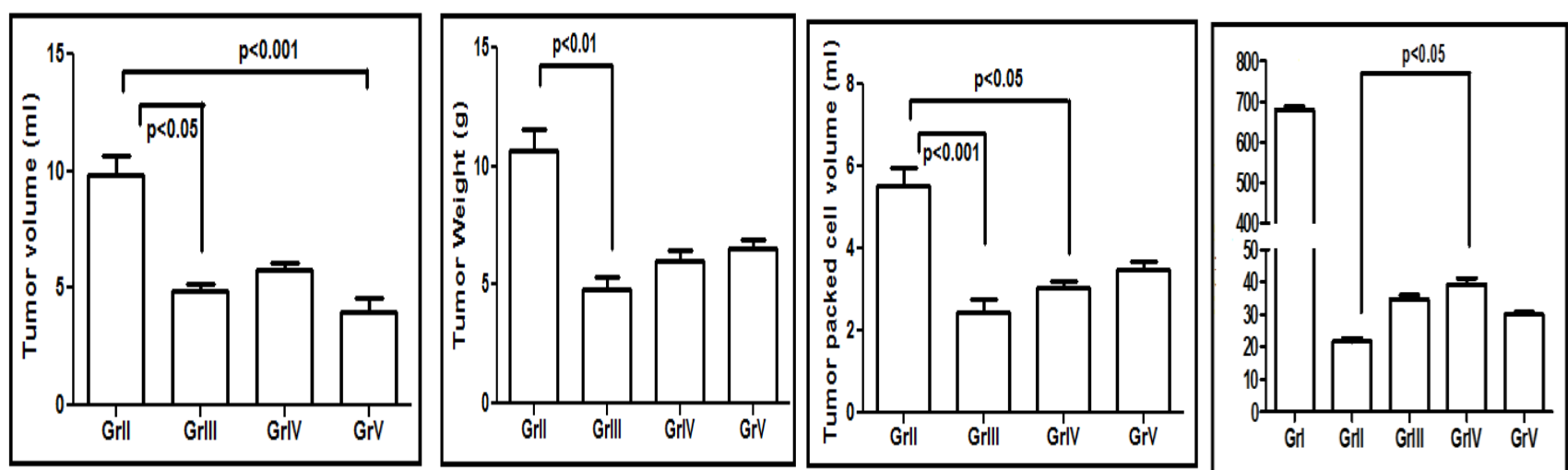

Swiss albino mice (Group 1), were then inoculated with $1 \times 10^{6}$ EAC cells (Group II) and treated with Methotrexate $(0.4 \mathrm{mg} / \mathrm{kg}$ b.w., Group III) or rampatri (50 or $100 \mathrm{mg} / \mathrm{kg}$ b.w., Groups IV or V) for 9 consecutive days as described in Materials and methods. Data are expressed as the mean \pm SEM, $(n=6)$ in each experimental group.

Figure 2: Effect of rampatri on tumor characteristics. (A) Tumor volume, (B) Tumor weight, (C) Tumor packed cell volume, (D) Mean survival time (MST) were evaluated in Swiss albino mice.

\section{Tumor weight}

A substantial increase in tumor weight was observed in the EAC animal model being $10.63 \pm 0.95 \mathrm{~g}$ which decreased significantly by 2.06 fold with the addition of MTX to $4.80 \pm 0.56 \mathrm{~g}(\mathrm{p}<0.01$, Figure 2B). Rampatri (50 and 100 $\mathrm{mg} / \mathrm{kg}$ bw. Groups IV and V) also demonstrated a 1.76 and 1.62 fold decrease in tumor weight to $6.02 \pm 0.40$ and $6.54 \pm 0.35 \mathrm{~g}$ respectively (Figure $2 \mathrm{~B}$ ).

\section{Tumor packed cell volume}

Following the addition of MTX (Group III), the increased tumor packed cell volume in the EAC model $(5.51 \pm 0.47 \mathrm{ml})$ substantially decreased by 2.2 . fold to $2.46 \pm 0.29 \mathrm{ml}, \mathrm{p}<0.001$, Figure 2C). Rampatri (50 and $100 \mathrm{mg} / \mathrm{kg}$ bw. Groups IV and V) also decreased the tumor packed cell volume by 1.8 fold $(3.04 \pm 0.18 \mathrm{ml}, \mathrm{p}<0.05$, Figure 2C) and 1.5 fold $(3.50 \pm 0.19 \mathrm{ml})$ respectively (Figure 2C).

\section{Increase in life span}

The Mean survival Time (MST) was decreased in the EAC control group $(21.67 \pm 1.11$ days $)$ in comparison with normal Swiss albino mice which remained alive for at least 6 months after the study was completed, indicating establishment of the tumor model (Figure 2D). The MST increased by 1.59 fold following treatment with MTX to $34.67 \pm 1.28$ days. Similarly, treatment with rampatri (Groups IV and V) increased the MST by $1.81(\mathrm{p}<0.05)$ and 1.38 fold respectively (Figure 2D).

\section{Hematological parameters}

In the tumor model, there was a significant decrease in the RBC and lymphocyte count, hemoglobin, hematocrit, mean corpuscular volume. Treatment with rampatri or MTX restored these parameters except for the lymphopenia which persisted (Table 1). 
Table 1: Effects of rampatri on hematological parameters of EAC model.

\begin{tabular}{|c|c|c|c|c|c|}
\hline \multirow[b]{2}{*}{ Parameters } & \multicolumn{5}{|c|}{ Group (drug, mg/kg b.w., i.p.) } \\
\hline & $\begin{array}{l}\text { Group I } \\
\text { (normal) }\end{array}$ & $\begin{array}{l}\text { Group II } \\
\text { (No drug) }\end{array}$ & $\begin{array}{l}\text { Group III } \\
\text { (MTX, } \\
\text { 0.4 mg/kg b.w.) }\end{array}$ & $\begin{array}{l}\text { Group IV } \\
\text { (Rampatri, } \\
\mathbf{5 0 ~} \text { mg/kg b.w.) }\end{array}$ & $\begin{array}{l}\text { Group V } \\
\text { (Rampatri, } \\
\text { 100mg/kg b.w.) }\end{array}$ \\
\hline $\mathrm{WBC}\left(\times 10^{3} / \mu \mathrm{l}\right)$ & $11.25 \pm 0.93$ & $23.20 \pm 1.79 *$ & $10.87 \pm 0.77^{\#}$ & $13.25 \pm 0.77^{\#}$ & $12.07 \pm 0.67^{\#}$ \\
\hline $\mathrm{RBC}\left(\times 10^{6} / \mu \mathrm{l}\right)$ & $8.53 \pm 0.87$ & $4.49 \pm 0.24 *$ & $6.96 \pm 0.76^{\#}$ & $7.47 \pm 0.33^{\#}$ & $7.42 \pm 0.10^{\#}$ \\
\hline $\mathrm{Hb}(\mathrm{g} / \mathrm{dl})$ & $13.00 \pm 1.31$ & $8.30 \pm 0.30 *$ & $10.92 \pm 0.75^{\#}$ & $12.55 \pm 0.24^{\#}$ & $11.78 \pm 0.41^{\#}$ \\
\hline $\operatorname{HCT}(\%)$ & $42.95 \pm 1.45$ & $26.15 \pm 1.28 *$ & $32.07 \pm 1.17 * \#$ & $34.02 \pm 1.22 * \#$ & $35.55 \pm 1.34 * \#$ \\
\hline $\operatorname{MCV}(\mathrm{fl})$ & $51.80 \pm 1.08$ & $56.88 \pm 1.37$ & $47.08 \pm 1.07^{\#}$ & $46.15 \pm 1.22 * \#$ & $47.23 \pm 1.35^{\#}$ \\
\hline $\operatorname{PLT}\left(\times 10^{3} / \mu \mathrm{l}\right)$ & $359.8 \pm 46.61$ & $344.2 \pm 55.57$ & $276.2 \pm 37.62$ & $482.0 \pm 41.39^{\$}$ & $527.3 \pm 56.90^{\$}$ \\
\hline LYM $(\%)$ & $76.48 \pm 3.81$ & $28.23 \pm 1.71 *$ & $32.1 \pm 3.30 *$ & $35.40 \pm 3.41 *$ & $36.78 \pm 2.67 *$ \\
\hline
\end{tabular}

$* \mathrm{p}<0.05$ compared with Group I; \#p<0.05 compared with Group II; \$p<0.05 compared with Group III

Table 2: Effects of rampatri on hepatic and renal functions of EAC bearing male Swiss Albino mice.

\begin{tabular}{|llllll|} 
& $\begin{array}{l}\text { Group I } \\
\text { Parameters }\end{array}$ & $\begin{array}{l}\text { Group II } \\
\text { (No drug) }\end{array}$ & $\begin{array}{l}\text { Group III } \\
\text { (MTX, } \\
\mathbf{0 . 4 m g / k g ~ b . w . ) ~}\end{array}$ & $\begin{array}{l}\text { GroupIV } \\
\text { (Rampatri, } \\
\mathbf{5 0 m g / k g ~ b . w . ) ~}\end{array}$ & $\begin{array}{l}\text { Group V } \\
\text { (Rampatri, } \\
\mathbf{1 0 0 m g / k g ~ b . w . ) ~}\end{array}$ \\
\hline Urea (mg/dl) & $50.17 \pm 3.29$ & $33.15 \pm 1.49$ & $31.00 \pm 1.93$ & $37.83 \pm 1.13$ & $33.83 \pm 1.60$ \\
\hline Creatinine (mg/dl) & $0.53 \pm 0.04$ & $0.37 \pm 0.10$ & $0.58 \pm 0.09$ & $0.45 \pm 0.02$ & $0.36 \pm 0.01$ \\
\hline SGOT(U/L) & $40.83 \pm 3.80$ & $51.92 \pm 7.08$ & $76.33 \pm 7.03$ & $270.2 \pm 6.90^{* \# \$}$ & $276.3 \pm 21.22^{* \# \$}$ \\
\hline SGPT(U/L) & $42.17 \pm 5.82$ & $43.00 \pm 2.33$ & $91.50 \pm 9.55^{*}$ & $44.83 \pm 1.95^{\#}$ & $42.17 \pm 2.54^{\$}$ \\
\hline
\end{tabular}

* $\mathrm{p}<0.05$ compared with Group I; \#p<0.05 compared with Group II; \$p<0.05 compared with Group III

\section{Effect of rampatri on renal and hepatic functions}

Levels of urea and creatinine remained unchanged across all groups (Table 2). The serum SGOT in the EAC control group (group II) was comparable with group I, but both doses of rampatri (group IV and V) significantly increased the serum SGOT levels ( $p<0.05$, Table 2$)$. In the EAC control group, serum SGPT levels were unchanged (Table 2), but MTX (group III) significantly increased the SGPT levels by 1.3 fold as compared to the EAC treated group ( $p<0.05$, Table 2$)$, but was not observed with rampatri.

\section{DISCUSSION}

The anticancer properties of malabaricones derived from rampatri have been demonstrated in cancer cell lines and the cytotoxicity attributed to its ability to trigger a redox imbalance, possibly secondary to its $\mathrm{Cu}$ (II)-dependent nuclease property. ${ }^{4-6,8,9}$ The maintenance of redox homeostasis within cells is essential for the survival of a cell and in the perspective of cell metabolism, cancer cells adapt themselves to handle the redox imbalance by developing strategies that make them become insensitive to stress inducers such as chemotherapy and radiation. ${ }^{10}$ However, the excessive induction of ROS by compounds such as malabaricones have been proposed reactive oxygen species to be potential therapeutic tools against cancers. $^{4,8-10}$

The pathogenesis of malignant ascites involves injury to the peritoneal serosa by malignant cells leading to increased vascular permeability, edema formation, cellular migration and progressive ascitic fluid accumulation. This ascitic fluid serves as a direct nutritional source for tumor cells allowing for tumor growth. This was demonstrated in the EAC model where the increase in tumor parameters e.g. tumor volume, tumor weight and tumor packed cell volume in EAC bearing mice was demonstrated (Figure 2). Importantly, the reduction of these tumor parameters by rampatri along with prolongation of the life span of tumor bearing animals endorsed the anti-tumor activity of rampatri in an animal model, endorsing in vitro studies performed in cell lines. ${ }^{4,8,9}$

The major drawback of cancer chemotherapy includes myelosuppression and anemia, and the ability of rampatri to improve the hematological profile suggested that the compound did not adversely impact on hematopoiesis, and was in concordance with toxicity studies that demonstrated it was non-toxic till 2000mg. ${ }^{11-14}$ Furthermore, the unchanged renal functions endorsed the minimal toxic effect of rampatri.

However, rampatri caused a significant increase in SGOT perhaps secondary to its pro-oxidant property. Taken together, rampatri displayed promising in vivo antitumor activity and minimal toxicity endorsing further in vivo studies be undertaken with its active phytoconstituents, namely malabaricones. ${ }^{4,8,9}$

Funding: Funding by Improvement of $S$ and $T$ Infrastructure in Universities and Higher Educational Institutions (FIST) Program, Dept. of Science and Technology, Govt. of India (DST-FIST) [Grant number: SR/FST/LS1-663/2016] 
Conflict of interest: None declared

Ethical approval: The study was approved by the Institutional Ethics Committee (IAEC, 544/PO/c/02/CPCSEA)

\section{REFERENCES}

1. Morita $\mathrm{T}$, Jinno $\mathrm{K}$, Kawagishi $\mathrm{H}$, Arimoto $\mathrm{Y}$, Suganuma H, Inakuma $T$, et al. Hepatoprotective effect of Myristica from nutmeg (Myristica fragrant) on lipopolysaccharide/d-galactosamine-induced liver injury. J Agric Food Chem. 2003;51:1560-5.

2. Banerjee D, Bandyopadhyay SK, Bauri AK, Chattopadhyay S. Healing properties of malabaricone $\mathrm{B}$ and malabaricone $\mathrm{C}$, against indomethacin-induced gastric ulceration and mechanism of action. Eur $\mathrm{J}$ Pharmacol. 2008;578:300-12.

3. Sen R, Bauri AK, Chattopadhyay S, Chatterjee M. Antipromastigote activity of the malabaricones of Myristica malabarica(Rampatri) Phytother Res. 2007;21:592-5.

4. Manna A, Saha P, Sarkar A, Mukhopadhyay D, Bauri AK, Kumar D, et al. Malabaricone-A induces a redox imbalance that mediates apoptosis in U937 cell line. PLoS One. 2012;7:e36938.

5. Patro BS, Bauri AK, Mishra S, Chattopadhyay S. Antioxidant activity of Myristica malabarica extracts and their constituents. J Agric Food Chem. 2005;53:6912-8.

6. Tyagi M, Bhattacharyya R, Bauri AK, Patro BS, Chattopadhyay S. DNA damage dependent activation of checkpoint kinase-1 and mitogen-activated protein kinase-p38 are required in malabaricone $\mathrm{C}$-induced mitochondrial cell death. Biochim Biophys Acta. 2014;1840:1014-27.

7. Bala A, Kar B, Haldar PK, Mazumder UK, Bera S. Evaluation of anticancer activity of Cleome gynandraon Ehrlich's Carcinoma treated mice. J Ethnopharm. 2010;129:131-4.
8. Manna A, Bauri AK, Chattopadhyay S, Chatterjee M. Effectiveness of Malabaricone-A in a multidrug resistant cell line is mediated via generation of redox imbalance. Anticancer Agents Med Chem. 2015;15:1156-63.

9. Manna A, De Sarkar S, De S, Bauri AK, Chattopadhyay S, Chatterjee M. The variable chemotherapeutic response of Malabaricone-A in leukemic and solid tumor cell lines depends on the degree of redox imbalance. Phytomed. 2015;22:71323.

10. Manna A, Chattopadhyay S, Chatterjee M. Plant derived pro-oxidants as potential anti-cancer therapeutics. 2016; Studies in Natural Products Chemistry; Atta-ur- Rahmaned (Bioactive Natural Products), Elsevier, Amsterdam; 2016;81-92.

11. Haldar PK, Kar B, Bala A, Bhattacharya S, Mazumder UK. Antitumor activity of Sansevieria roxburghiana rhizome against Ehrlich ascites carcinoma in mice. Pharm Biol. 2010;48:1337.

12. KunduSen S, Gupta M, Mazumder UK, Haldar PK, Saha P, Bala A et al. Antitumor activity of Citrus maxima (Burm.) Merr. Leaves in Ehrlich's Ascites Carcinoma Cell-treated mice. ISRN Pharmacol. 2011;138737.

13. Ozaslan M, Karagoz ID, Kilic IH, Guldur ME. Ehrlich ascites carcinoma. J Home. 2011;10:13.

14. Manjunatha BK, Mankani KL, Mukunda SK, Divakara R, Sridar BK and Paul K. Antioxidant and hepatoprotective effect of Myristica malabarica seed aril extracts on carbon tetrachloride induced hepatic damage. Global J Biotechnol Biochem. 2011;6:25-30.

Cite this article as: Bandyopadhyay C, Manna A, De S, Yasmin N, Bauri AK, Chattopadhyay S, et al. Anti-tumor effect of fruit rind of Myristica malabarica in an Ehrlich ascites carcinoma model. Int J Basic Clin Pharmacol 2019;8:383-7. 